INTERDISCIPLINARIA ARCHAEOLOGICA NATURAL SCIENCES IN ARCHAEOLOGY

\title{
The Early-Merovingian Cemetery in München-Perlach (Bavaria) - Analysing Skeletal Morphology, Health and Disease and Strontium Isotope Ratios
}

\author{
Kristin von Heyking ${ }^{\mathrm{a}}$, Stephanie Zintt ${ }^{\mathrm{b}, \mathrm{c}^{*}}$ \\ aAnthroArch GbR, Josef-Danzer-Str. 35, 82152 Planegg, Germany \\ ${ }^{b}$ Institute of Archaeological Sciences, Albert-Ludwigs-Universität, Freiburg i. Br., Germany \\ 'Bavarian State Department for Preservation of Historical Monuments, Office Thierhaupten, Klosterberg 8, 86672 Thierhaupten, Germany
}

\section{ARTICLE INFO}

\section{Article history:}

Received: $11^{\text {th }}$ December 2015

Accepted: $2^{\text {nd }}$ September 2016

\section{Key words:}

Early Middle Ages

cemetery

Bavaria

living conditions

personal mobility

stress marker

cribra orbitalia

enamel hypoplasia

strontium isotopes analysis

\begin{abstract}
$A B S T R A C T$
The present study focuses on the living conditions and mobility of individuals buried in MünchenPerlach at around $500 \mathrm{AD}$, using archaeological, morphological and archaeometric methods. The sex, age at death, and body height of each individual were ascertained with the aid of morphological examination techniques. The skeletal series is characterised by a balanced sex distribution and a surprisingly high life expectancy for Merovingian times. Compared to the contemporary, (possibly) high status collectives Unterhaching and Burgweinting the morphological stress markers cribra orbitalia and enamel hypoplasia suggest slightly less favourable living conditions for the MünchenPerlach individuals. However, it has to be stressed that further research and more comparative studies are needed to interpret these results.

The isotopic analyses of strontium ratios of the tooth enamel of 29 individuals from the MünchenPerlach cemetery suggest that at least four individuals did not grow up in the region. The strontium signatures of these four people indicate that they consumed food from a granite or volcanic geologic substrate in their childhood, which identifies them as foreign to the region where they were buried.
\end{abstract}

\section{Introduction}

Due to the almost complete absence of written sources only a few (and often scattered) pieces of information exist as to population development and the composition of society in early medieval Bavaria around 500 AD. Our knowledge is almost exclusively based on archaeological finds, most notably burials furnished with grave goods that are characteristic for this period and so far have attracted most attention. The present study attempts to complement archaeological findings on a small cemetery from early Merovingian times in München-Perlach with the results of morphological and (molecular) archaeometric analyses of the skeletons to get a better understanding of the living conditions and potential mobility of the individuals buried there.

In 1999, excavations of Roman structures dating from the $1^{\text {st }}$ to the middle of the $4^{\text {th }}$ century (Volpert 2004/05) in the

*Corresponding author. E-mail: Stephanie.Zintl@blfd.bayern.de village of Perlach, nowadays a suburb in the south of Munich, also yielded a small cemetery dating to early Merovingian times (Zintl 2004/05). In total, 32 burials were excavated. Two more graves might have been destroyed by modern construction work (graves no. 33 and 34, cf. Figure 1), and the burial place was not excavated completely, but two burials of small children (graves no. 31 and 32) found in 2000 indicate its eastern border. Thus, it can be assumed that probably at least two thirds of the cemetery have been excavated.

The cemetery lies close to a small river, the Hachinger Bach which runs south to north and also marks the approximate course of a traffic route in this region: Archaeological sites from Roman and Early Medieval times line up along this route ( $c f$. Winghart 1995), including the richly-furnished early Merovingian graves from Unterhaching that were found only about $5 \mathrm{~km}$ south of the Perlach cemetery in 2004 (Fehr, Later, Volpert 2005; Wamser 2010; Haas-Gebhard 2013). The settlement to which the cemetery in Perlach belonged has not yet been found. The relation of the early Merovingian graves to a larger cemetery approximately $150 \mathrm{~m}$ further west, where 


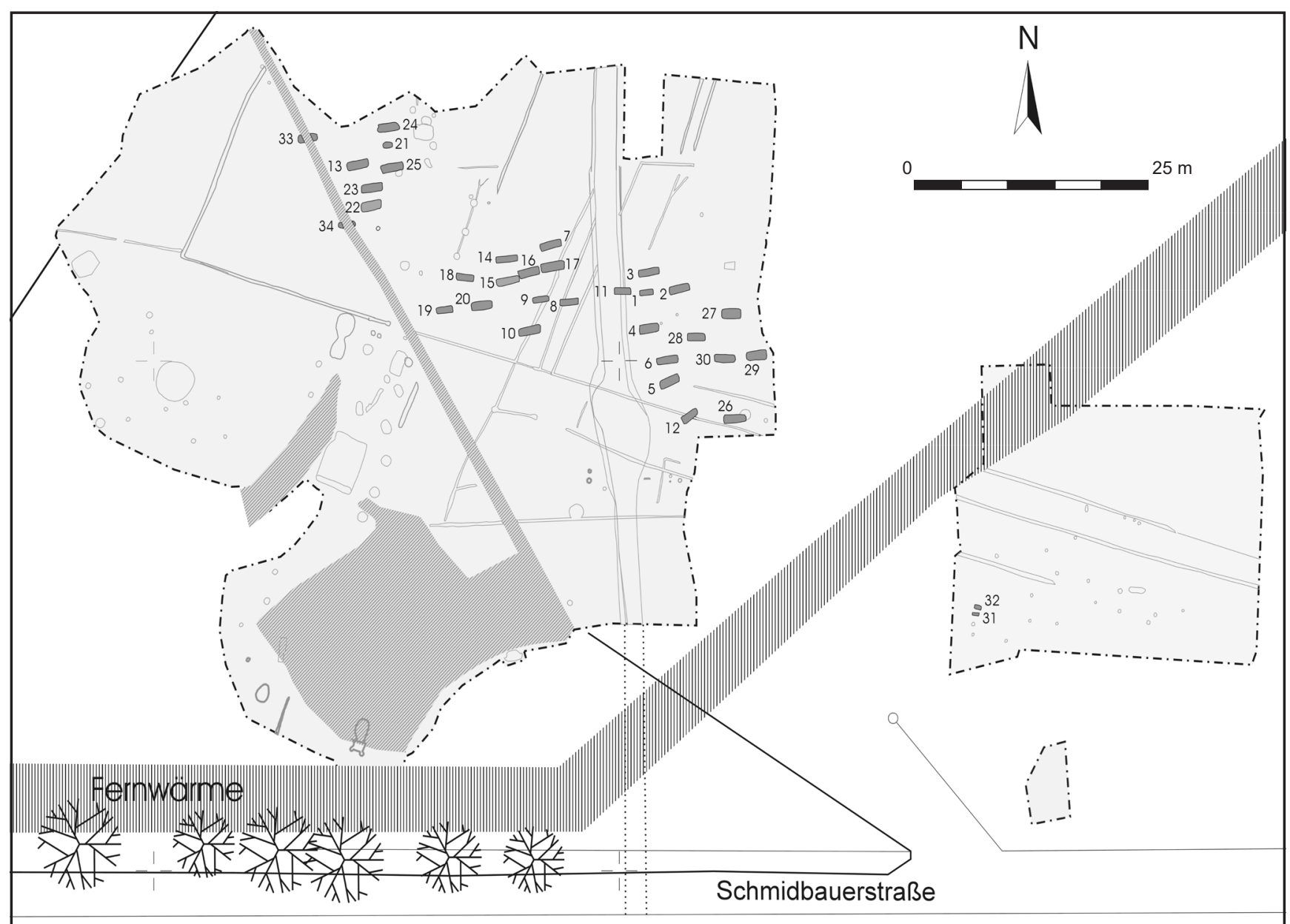

Figure 1. Plan of the cemetery in München-Perlach, Schmidbauerstraße; excavations in 1999 and 2000.

an unknown number of graves dating to the $7^{\text {th }}$ century AD were destroyed in 1968, remains unclear.

All 32 burials in Perlach are single inhumation burials: the skeletons supine with their heads to the west of the grave. The grave pits are comparatively deep for Early Medieval graves in the Munich gravel plain, with most depths ranging between about $1 \mathrm{~m}$ and $1.3 \mathrm{~m}$ under the excavation's ground level (measured after the top soil was removed); something that seems to be typical of graves from earliest Merovingian times in the region (H.-P. Volpert, pers. comm.). The graves are quite narrow, with widths between about 0.4 and $0.7 \mathrm{~m}$ at the level of the skeleton. In a few cases the remains or stains of wood indicate narrow wooden coffins or, in at least one case (grave no. 7), burial in a tree-trunk coffin. In other graves the positions of the skeletons' upper extremities being very close to the body also suggest burial in tree-trunk coffins. This fits well with the cemetery's date, since tree-trunk coffins are a common characteristic of early Merovingian graves in southern Germany (Zintl 2004/05: 342). In grave no. 28 a pottery vessel was deposited in a sort of niche at the narrow end of the grave pit, west of the child's head. Except for a small vessel in another child's grave (grave no. 1), this is the only evidence of the deposition of vessels or food in the whole cemetery.
The dead were buried in their clothes, but - as is typical of early Merovingian times - male graves were furnished very sparsely: most male burials only contained a knife and/or a simple belt buckle. The man in grave no. 13 was the only one who was buried with a weapon, namely a very small seax (a single-edged bladed sword typical for Merovingian times), and some tools in a small bag. Seven of the women and a child were buried with brooches, but notably none of them wore a full set of four brooches and all bow brooches occur as single pieces only (all graves in the cemetery are undisturbed). Other dress accessories and jewellery include glass and amber beads, that were worn around the neck, around the waist or hanging from the belt, and knives, metal rings and other small things, also worn hanging from the belt. The woman in grave no. 4 was buried with a set of three iron keys and an iron sieve spoon - such spoons are usually made of silver and thought to have been used for serving spiced wine (Knaut 1993, 103; Martin 1984; Zintl 2004/05, 300). Both the small finds and the burial customs allow dating the graves to the later part of the $5^{\text {th }}$ and the early $6^{\text {th }}$ centuries AD; the cemetery was used for burial for approximately 50 or 60 years. 


\section{Anthropological methods}

\subsection{Morphology (age and sex diagnosis, estimation of body height)}

Methods of morphologicalage-of-death and sex determination and body height calculation, as well as the respective results and discussion, can be taken from the contribution by Harbeck et al. (2016). Methods of sex determination for children, as well as the respective results for the burial sites Burgweinting Nord-West II and Burgweinting Kirchfeld-West can be taken from Schleuder and Codreanu-Windauer (2013). For analysing paleodemographic parameters the collective under study was first tested as to its representativeness according to the formulae of Bocquet and Masset (1977), after which life tables were calculated ( $c f$. Acsádi, Nemeskéri 1970).

\subsection{Unspecific stress markers}

The term "unspecific stress markers" is used for pathological changes in bones or teeth which cannot be attributed to a certain defined disease (Lewis, Roberts 1997). In the present study cribra orbitalia as well as enamel hypoplasias were evaluated.

Cribra orbitalia are defined as porous or sieve-like foramina of the so-called lamina externa in the region of the orbital roof. In this study they were classified into two stages according to the size of the covered area in the orbit (Steckel et al. 2005; cf. Table 1); at least one orbit had to be present and observable.

Enamel hypoplasias are defects concerning the thickness of the dental enamel layer manifesting themselves as linear, pit-like or more or less extended enamel mineralization disorders (Goodman, Rose 1990; Hillson, Bond 1997). They result from stress phases affecting an individual during the period of enamel formation (amelogenesis) in their infancy or childhood: the formation of enamel by ameloblasts is disturbed resulting in structural disorders in the form of hypoplastic defects (Goodman, Rose 1990). Once developed, the dental enamel is not remodelled during the further life of an individual, thus being an irreversible indicator of stress during infancy or early childhood.
Transversal enamel hypoplasias are classified into three stages depending on the degree of their expression (Global History of Health Project 2005, after Schultz 1988) (cf. Table 2).

The age of formation of an enamel hypoplastic defect was determined by comparison with the dental development scheme of Massler et al. (1965).

\section{Results and discussion}

\subsection{Sex ratio and distribution of age-of-death}

The results for each individual regarding age-of-death, sex, body height, cribra orbitalia, enamel hypoplasia and the strontium isotope measurements are listed in Table 6.

Of the 32 individuals examined $90.6 \%(\mathrm{n}=29)$ can be sexed: $31.2 \%(\mathrm{n}=10)$ are determined as female, $9.4 \%(\mathrm{n}=3)$ as likely female, $25 \%(\mathrm{n}=8)$ as male and a further $25 \%(\mathrm{n}=8)$ as likely male. Thus $9.4 \%(\mathrm{n}=3)$ of the Perlach individuals are of indeterminate morphological sex. Combining the respective categories "female" and "likely female" as well as "male" and "likely male" results in $40.6 \%$ female individuals versus $50 \%$ male individuals.

A morphological age-of-death diagnosis was possible for all of the 32 individuals (Table 3 ).

Figure 2 shows the sex distribution within the different age classes of the total collective (for details see: Haebler et al. 2006, Table 1).

Of the 32 individuals buried in the Perlach cemetery $25 \%$ $(\mathrm{n}=8)$ are children (age classes Infans1 and Infans2). Other Early Medieval necropoles show lower percentages of child burials, for example: Unterhaching, only 10\% (Harbeck et al. 2013); Burgweinting Kirchfeld-West 15.8\%; Burgweinting Nord-West II 13.4\% (Harbeck et al. 2016); and Altenerding $16.6 \%$ (Zink 1999). The mortality of children (reflected in their proportion of the cemetery collective) is regarded as an indicator of the living conditions ( $c f$., for example, Grupe et al. 2005). However, since the proportion of child burials in Early Medieval cemeteries is in most cases quite small, it is usually assumed that either not all of the individuals

Table 1. Standard for scoring cribra orbitalia.

\begin{tabular}{cl}
\hline Stage & \multicolumn{1}{c}{ Degree of expression } \\
\hline 0 & No orbits present for observation \\
1 & Absent with at least one observable orbit \\
2 & A cluster of mostly fine foramina covering a small area $\left(\leq 1 \mathrm{~cm}^{2}\right)$ \\
3 & Substantial area $\left(>1 \mathrm{~cm}^{2}\right)$ covered by small and/ or larger foramina with a tendency to cluster together \\
\hline
\end{tabular}

Table 2. Standard for scoring enamel hypoplasias.

\begin{tabular}{|c|c|}
\hline Stage & Degree of expression \\
\hline 0 & Tooth not present or unobservable \\
\hline 1 & No linear enamel hypoplasia \\
\hline 2 & One hypoplastic line present \\
\hline 3 & Two or more hypoplastic lines present \\
\hline
\end{tabular}




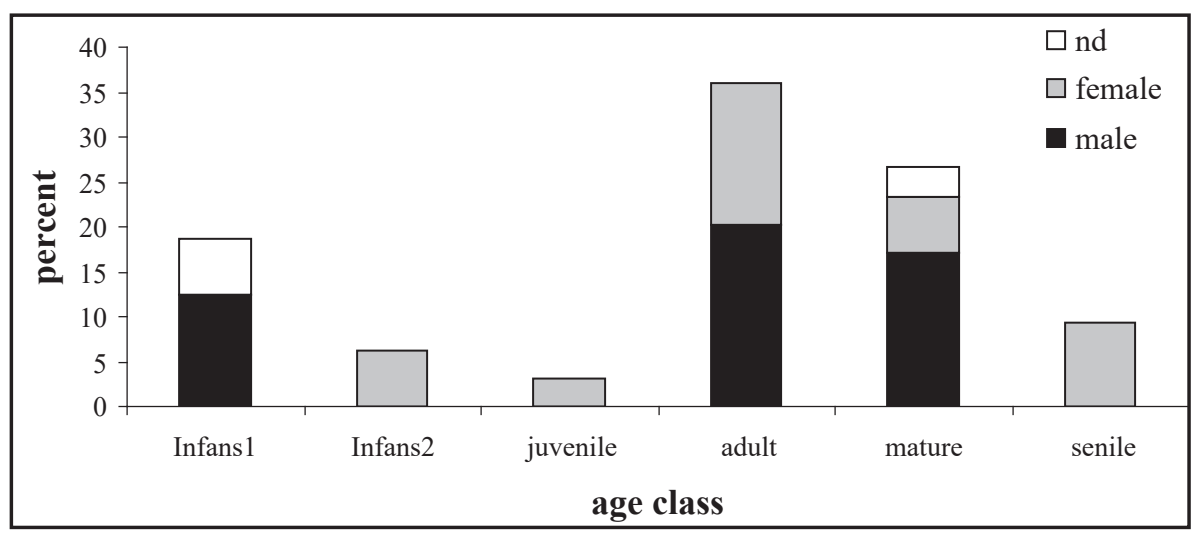

Figure 2. Distribution of morphological age and sex.

Table 3. Age distribution in München-Perlach.

\begin{tabular}{lcc}
\hline \multicolumn{1}{c}{ Age class } & Absolute number (n) & Percentage \\
\hline Infans1 (0-6 years) & 6 & $18.80 \%$ \\
Infans 2 (7-12 years) & 2 & $6.20 \%$ \\
juvenile (13-20 years) & 1 & $3.10 \%$ \\
adult (21-40 years) & 11 & $34.40 \%$ \\
mature (41-60 years) & 9 & $28.10 \%$ \\
senile (60+ years) & 3 & $9.40 \%$ \\
\hline total & 32 & $100 \%$ \\
\hline
\end{tabular}

who died already as an infant or child were buried in the regular cemeteries, or that the graves of children are underrepresented due to other circumstances, as, for example, the poor preservation prospects of bones (summarised in Lohrke 2004, 38-40; Herrmann et al. 1990). The comparably high proportion of individuals who died early in the MünchenPerlach collective might reflect the real mortality of infants and children somewhat better (for details, see below).

Among the buried individuals of juvenile age or higher age classes a balanced sex ratio is observed in the Perlach population, even though the cemetery was not excavated completely: 12 male individuals versus 11 female individuals - as opposed to the contemporary necropoles of Unterhaching and Burgweinting which are characterized by a significant female surplus (cf. Harbeck et al. 2013; Harbeck et al. 2016).

Most individuals in Perlach had died in the adult age class (34.4\%), followed by those of the mature age class $(28.1 \%)$. A similarly balanced ratio can be observed in Burgweinting Nord-West II (see Harbeck et al. 2016). In contrast to this, more individuals had died in the mature than in the adult age class in Burgweinting Kirchfeld-West and in Unterhaching (Harbeck et al. 2013). A shift to mature age-of-death, showing longer life spans of individuals, indicates better living conditions. Yet, one should keep in mind that the small sample size can only show tendencies - for more farreaching comparative interpretations more populations with more individuals would be necessary.

The senile age-class comprised female individuals only; accordingly, more male individuals had died in the adult and mature age class in the München-Perlach collective.

\subsection{Paleodemography}

To obtain further information for the reconstruction of demographic processes, life expectancy and mortality rate were calculated for the collective of München-Perlach. For all of the following calculations and discussion thereof, the small sample size of only 32 individuals and also the fact that the cemetery was not excavated completely should be kept in mind. Thus, all of the following only indicates tendencies. Statistical tests were not applied due to the small sample size.

A methodically correct analysis of paleodemographic structures first requires validating the collective under study with regard to its representativeness.

For that purpose two quotients had to be calculated: the ratio of the 5- to 9-year-old individuals to the 10- to 14-yearold individuals (expected value: $\geq 2$ ), as well as the ratio of the 5- to 14-year-old individuals to the grown-ups $\geq 20$ years (expected value: $\geq 0.1$ ) (after Bocquet, Masset 1977). The first-mentioned ratio comes to 13.3 in the collective under study, thus meeting the expectations. The ratio of the number of 5- to 14-year-old individuals to the number of adult/ mature/senile individuals is 0.175 in München-Perlach, again corresponding to the expected value of $\geq 0.1$. Despite the cemetery's incomplete excavation, the Munich-Perlach collective seems to be representative.

In the following, life expectancies and mortality rates will be compared. A fundamental requirement is the presence of valid individual data as to age-of-death and sex (Grupe et al. 2005).

In Figure 3 the sex-specific life expectancy of the individuals of München-Perlach is shown (values calculated by means of a life table).

Average life expectancy at birth is 28.9 years for male individuals and 36.4 years (a conspicuously high value) for female individuals. However, a deficit of infants being buried ( $c f$. above) can lead to an "artificially increased" average life expectancy at birth and at the same time to an unrealistically low mortality (rate) in the age class of infants (Grupe et al. 2005) (see Figures 3 and 4). The mentioned "infant deficit" is often observed in historical graveyard collectives ( $c f$. Strott 2006; Zink 1999) and may be postulated for MünchenPerlach, too, as female infants seem to be missing completely in this collective. Therefore the real female life expectancy at birth was probably lower than that shown in the diagram. 
Figure 3. Life expectancy (years) for males and females of the München-Perlach collective.

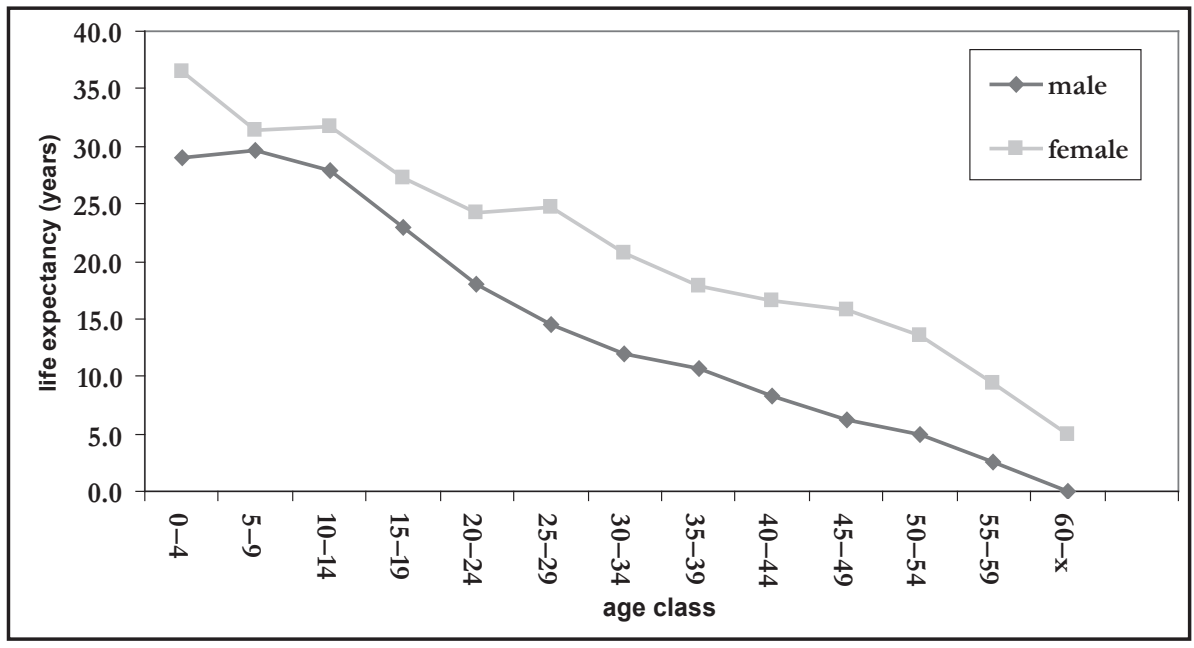

The phenomenon of higher life expectancies for female individuals is seen in all age classes. A maximum difference of slightly more than 10 years can be noticed for the age span of 25 to 29 years. Beyond the age of 45 years a gradual adjustment can be observed.

According to Langenscheidt (1985) a life expectancy at birth of more than 26 years - here true for both sexes indicates generally good living conditions.

Figure 4 shows the life expectancy values of the population of München-Perlach compared to the two collectives of Burgweinting (male and female individuals are combined in this diagram).

Life expectancy is considerably higher for the individuals from both Burgweinting necropoles, the difference being at least around 2 to 3 years on average. In a comparative study of different Early-Medieval graveyard populations, Langenscheidt (1985) found that average life expectancy at birth in those times was 22 to 29 years. Yet in the case of the München-Perlach individuals it is even a little higher at 31 years. Factors influencing life expectancy are, for example: hygienic conditions, food supply and diseases (children's diseases, infectious diseases, etc.). A higher life expectancy can therefore be seen as an indication of a generally better supply situation. Conditions seem to have been slightly above average in München-Perlach, and yet still considerably poorer than in Burgweinting. However, this conclusion should be taken with caution, as it is probable that the high life expectancy at birth in Perlach, and even more so in both Burgweinting necropoles, might be partly due to a deficit of infants' and children's burials in these cemeteries ( $c f$. above).

In Figure 5 the mortality rate of the München-Perlach collective is shown (male and female individuals separated).

The lowest mortality rate is found for individuals aged 10-14 years (with the exception of female individuals at birth; for possible reasons, see above), and thus in the age group with the "naturally" lowest risk of death within a population (Grupe et al. 2005). Another conspicuous aspect is the high female mortality in the early adult age of 20-24 years which can be explained by the potential risks coming with

Figure 4. Comparison of life expectancies; in the case of the Burgweinting collectives the authors used a different set of age classes (class size $>5 \mathrm{yrs}$ ), which explains the isolated dots in the diagram. Values for Burgweinting taken from Harbeck et al. (2016).

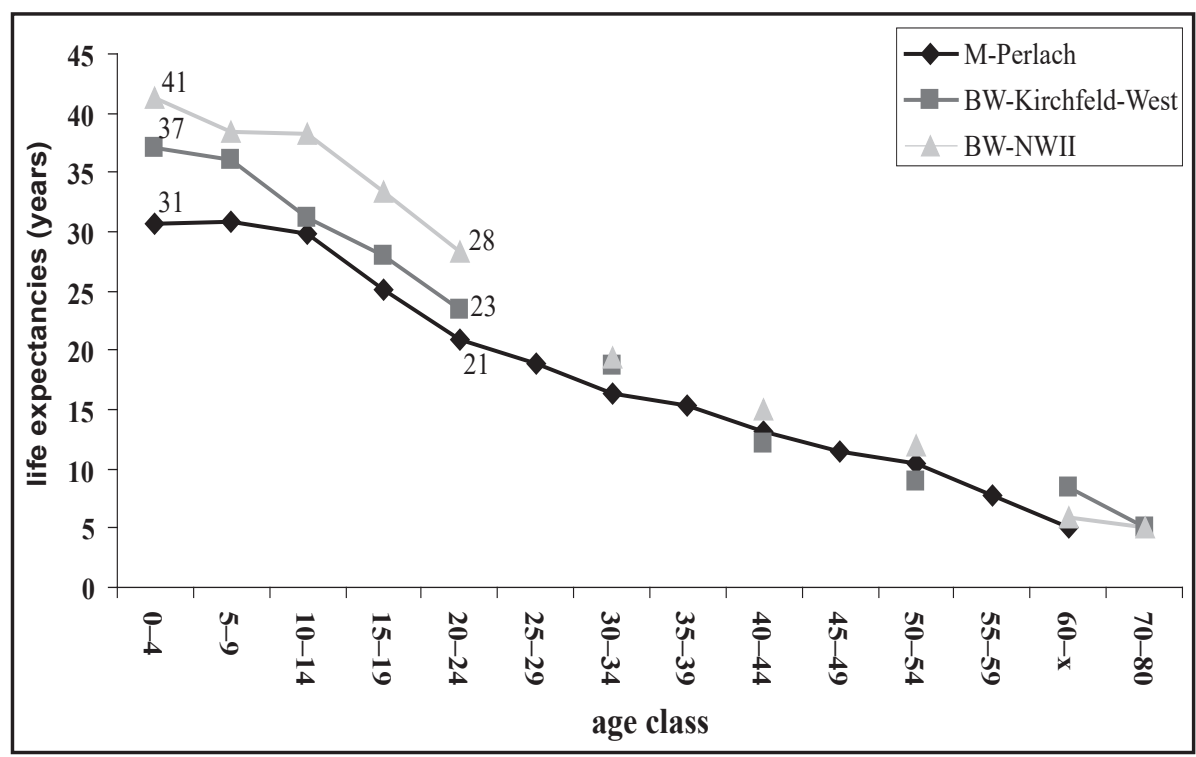




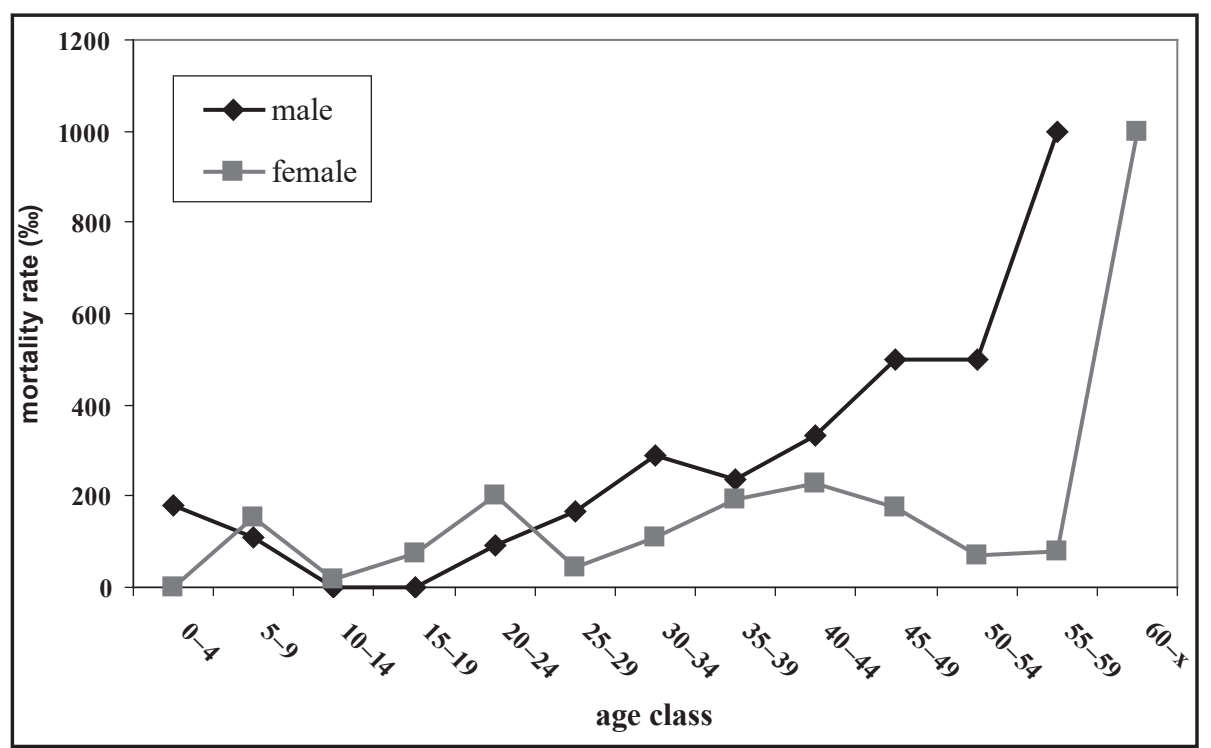

Figure 5. Mortality rate (\%o) for males and females of the München-Perlach collective.

pregnancy and childbirth (situations not unlikely at this age) (Wahl 1992). Once having survived this critical age, female individuals may have been more robust when facing diseases (cf. below) than male individuals whose mortality constantly increases after juvenile age. A reason for the latter may be seen in the male individuals bearing (and using) arms on reaching juvenile age (Kokkotidis 1999).

Yet, in the population of München-Perlach only a few traumatic bone lesions could be observed; however, these were exclusively in male individuals: a fracture of the left clavicle (age: 30-50 years; burial no. 22), a skull trauma caused by blunt force and a radius fracture both in one individual (age: 30-50 years; burial no. 23), and a fracture of a right metacarpal bone (age: 40-60 years; burial no. 27). All traumatic lesions had healed: in none of the Perlach individuals a fatal and/or unhealed trauma could be observed.

A medical study on sex-specific mortality showed that today men have a higher mortality than women. It is especially noteworthy that men are more sensitive to parasites and infectious diseases, which, moreover, are more often fatal in men than in women (Owens 2008). Such explanations valid for modern human populations may also be true for Early Medieval people.

\section{Stress markers}

\subsection{Stress markers: methodological background}

The term "stress" means physical or mental pressure on an individual. The interaction of man with his environment is of essential importance in this context. Any change in environmental conditions, as, for example, the evolution of new diseases or altered climatic conditions, requires some form of human adaptation, which is often connected to a higher stress level.

Traditional interpretations of pathological change are based on the following hypothesis: in general, people who are living under difficult conditions, being ill or undernourished show more strongly-expressed pathological lesions than the more privileged healthy parts of a population. This has been confirmed by comparative studies on cemetery collectives representing different social strata (cf. Bennike et al. 2005; Ribot, Roberts 1996; Timmermann 2009).

Skeletal manifestations of stress are, for instance, enamel hypoplasias and cribra orbitalia; these symptoms thus make stress "measurable". The incidence of certain stress markers and their relationship can provide information about the morbidity of a population (Ribot, Roberts 1996).

Cribra orbitalia can result from different (pathological) conditions: on the one hand, the anaemic conditions connected with hypertrophy of the erythropoietic bone marrow are held responsible for the porous reorganization of the orbit roof (e.g. Aufderheid, Rodriguez-Martin 1998). Frequently, acquired anaemias, resulting from iron deficiency, for instance, induce the forming of cribra orbitalia; the causes are a reduced iron intake due to deficient nutrition as well as to malabsorption, and/or chronic loss of blood in the intestines because of infections or a parasitic infestation (Schutkowski, Grupe 1997; Steinbock 1967). Walker et al. (2009), on the other hand, assume the cause to be a megaloblastic anaemia induced by a deficiency in folic acid or vitamin B 12. Other possible causes of cribra orbitalia are a lack of vitamin C (Grupe 1995; Sullivan 2005) or rickets (Ribot, Roberts 1996). According to histological studies, inflammation can also lead to hypervascularity and, by that, to the macroscopically-recognizable porosities of the orbits (Wapler et al. 2004).

Different causes are also given for the formation of enamel hypoplasia. Besides congenital malformations and traumata, metabolic stress is especially regarded as causative (Goodman, Rose 1990). In this context, for example, children's diseases and malnutrition have to be mentioned (Hillson, Bond 1997). 


\subsection{Stress markers: results}

The observed frequencies of cribra orbitalia and enamel hypoplasia are both listed in Table 6.

\subsection{Stress markers: discussion}

Table 4 demonstrates that the total frequency of cribra orbitalia in the Perlach population is comparable to the frequency in the Wenigumstadt collective, while considerably exceeding the values of Burgweinting and Unterhaching (the last-mentioned graveyard located at a distance of only $5 \mathrm{~km}$ from the Perlach necropolis).

Since the majority of cribra orbitalia develops during infancy or childhood, lesions observed in grown-up individuals are explained by insufficient bone remodelling, which allows the cribra orbitalia to persist up into adult age (StuartMacadam 1985). In the present study, a high frequency of subadult individuals showed cribra orbitalia. The observation that predominantly children were affected by cribra orbitalia is underpinned in München-Perlach by the fact that active and extensive lesions (stage 3 ) were found exclusively in the age classes Infans 1 or Infans 2 (see Table 6).

Neither rickets nor scurvy (resulting from vitamin $\mathrm{C}$ deficiency) could be diagnosed in the Perlach collective; both can therefore be excluded as possible causes in the observed cases of cribra orbitalia. In three individuals, periosteal changes - which can be induced by inflammatory processes - and cribra orbitalia were diagnosed together (grave no. 11, 21, and 31, all individuals subadult), so a combined cause for both lesions seems likely in these cases.

For the other individuals, an inadequate supply of, for example, vitamin B 12, or a case of heavy parasite infestation may have caused the cribra orbitalia.

When compared to other Early-Medieval burial sites (see Table 5), München-Perlach shows the highest frequency of enamel hypoplasia when considering the total population (44\%), whereas the hypoplasia incidence among the subadults alone $(16.7 \%)$ is found in the mid-range (because of the small sample size the Wenigumstadt collective cannot be regarded as representative here). In contrast to cribra orbitalia, which may disappear in adults due to lifelong bone remodelling, enamel hypoplasia, once developed, remains for life. The total frequency, therefore, is a considerably more significant aspect in a comparative interpretation of (historical) living conditions.

Not only the frequency of enamel hypoplasia but also the degree of its expression is of importance for an interpretation of individuals' living conditions. Two or more linear hypoplasia formed in one tooth crown (stage 3 ) reflect a recurrent or chronic stress situation having affected the infant or child. Almost half of the individuals concerned $(45.5 \%$, $5 / 11$; cf. Table 6) in the München-Perlach collective show stage 3 implying repeated phases of stress.

Table 4. Frequencies of cribra orbitalia in subadults and grown-up individuals from different necropoles. Data for Unterhaching, Wenigumstadt, and Burgweinting from Harbeck et al. (2016), for Altenerding-Klettham from Zink (1999).

\begin{tabular}{llccc}
\hline \multicolumn{4}{c}{ Cribra orbitalia } \\
\hline \multicolumn{1}{c}{ Skeletal series } & \multicolumn{1}{c}{ Dating/Historical period } & Total & Subadult & Adult (grown-ups) \\
\hline München-Perlach & late $5^{\text {th }}-$ early 6 th $^{\text {th }}$ century & $46.40 \%(13 / 28)$ & $87.50 \%(7 / 8)$ & $30 \%(6 / 20)$ \\
Unterhaching & around $500 \mathrm{AD}$ & $22.20 \%(2 / 9)$ & $50 \%(1 / 2)$ & $14.30 \%(1 / 7)$ \\
Burgweinting-Kirchfeld-West & late $5^{\text {th }}-$ early $6^{\text {th }}$ century & $36.80 \%(7 / 19)$ & $57.10 \%(2 / 3.5)$ & $32.30 \%(5 / 15.5)$ \\
Burgweinting-NWII & $5^{\text {th }}$ century & $38.50 \%(5 / 13)$ & $100 \%(2 / 2)$ & $27.30 \%(3 / 11)$ \\
Altenerding-Klettham & $5^{\text {th }}-7^{\text {th }}$ century (only Infans1 & & $47.20 \%(75 / 159)$ & \\
and Infans 2 investigated) & & & $33.30 \%(3 / 9)$ \\
Wenigumstadt & only individuals dated to the & $46 \%(5 / 11)$ & $100 \%(2 / 2)$ & \\
\hline
\end{tabular}

Table 5. Frequencies of enamel hypoplasias in subadults and grown-up individuals from different necropoles. Data for Unterhaching, Wenigumstadt, and Burgweinting from Harbeck et al. (2016), for Altenerding-Klettham from Zink (1999).

\begin{tabular}{|c|c|c|c|c|}
\hline \multicolumn{5}{|c|}{ Enamel hypoplasias } \\
\hline Skeletal series & Dating/ Historical period & Total & Subadult & Adult (grown-ups) \\
\hline München-Perlach & late $5^{\text {th }}-$ early $6^{\text {th }}$ century & $44 \%(11 / 25)$ & $16.70 \%(1 / 6)$ & $52.6 \%(10 / 19)$ \\
\hline Unterhaching & around $500 \mathrm{AD}$ & $22.20 \%(2 / 9)$ & $0 \%(0 / 1)$ & $25 \%(2 / 8)$ \\
\hline Burgweinting-Kirchfeld-West & late $5^{\text {th }}-$ early $6^{\text {th }}$ century & $31.60 \%(6 / 19)$ & $14 \%(0.5 / 3.5)$ & $35.50 \%(5.5 / 15.5)$ \\
\hline Burgweinting-NWII & $5^{\text {th }}$ century & $28.60 \%(4 / 14)$ & & $28.60 \%(4 / 14)$ \\
\hline Altenerding-Klettham & $\begin{array}{l}5^{\text {th }}-7^{\text {th }} \text { century (only Infans } 1 \\
\text { and Infans } 2 \text { investigated) }\end{array}$ & & $43.75 \%(35 / 80)$ & \\
\hline Wenigumstadt & $\begin{array}{l}\text { only individuals dated to the } \\
5^{\text {th }} \text { century investigated }\end{array}$ & $33.30 \%(3 / 9)$ & $100 \%(1 / 1)$ & $25 \%(2 / 8)$ \\
\hline
\end{tabular}


Table 6. Total results of the München-Perlach collective.

\begin{tabular}{|c|c|c|c|c|c|c|c|}
\hline Burial & Sex & $\begin{array}{l}\text { Age class } \\
\text { (years) }\end{array}$ & $\begin{array}{c}\text { Body height } \\
\text { (Bach/Breit.)(cm) }\end{array}$ & $\begin{array}{c}\text { Cribra } \\
\text { orbitalia }\end{array}$ & $\begin{array}{c}\text { Enamel } \\
\text { hypoplasia }\end{array}$ & $\mathrm{Sr}$ & Stand. \\
\hline 1 & prob. male & Infans1 (3-5) & 88.3 & 2 & 0 & 0.70897 & 0.000138788 \\
\hline 2 & nd & mature (40-60) & 165.1 & 0 & 0 & & \\
\hline 3 & prob. female & juvenile (13-20) & 169.8 & 1 & 3 & 0.70902 & 0.000103433 \\
\hline 4 & female & adult (20-24) & 163.8 & 1 & 3 & 0.70945 & 0.000197795 \\
\hline 5 & male & adult (20-24) & 175.8 & 1 & 1 & 0.70920 & 0.000023139 \\
\hline 6 & female & adult-mature (30-50) & 177.8 & 0 & 1 & 0.70867 & 0.000348799 \\
\hline 7 & prob. male & adult (24-40) & 159.7 & 1 & 1 & 0.70995 & 0.000551348 \\
\hline 8 & female & mature $(40-60)$ & 161.1 & 1 & 1 & 0.70877 & 0.000280209 \\
\hline 9 & prob. male & Infans1 (3-5) & 85.8 & 3 & 1 & 0.70914 & 0.00001858 \\
\hline 10 & prob. male & mature $(40-60)$ & 169.1 & 1 & 1 & 0.70957 & 0.000282648 \\
\hline 11 & male & Infans1 (4-6) & 95.0 & 2 & 1 & 0.70884 & 0.00023354 \\
\hline 12 & female & adult (25-35) & 166.8 & 1 & 2 & 0.70658 & 0.001827359 \\
\hline 13 & male & adult $(25-35)$ & 171.6 & 2 & 1 & 0.70865 & 0.000363648 \\
\hline 14 & male & adult (25-35) & 169.9 & 1 & 1 & 0.70961 & 0.000311639 \\
\hline 15 & male & mature $(40-60)$ & 172.5 & 1 & 2 & 0.70875 & 0.000296473 \\
\hline 16 & female & adult (24-40) & 168.0 & 1 & 2 & 0.70865 & 0.000365769 \\
\hline 17 & female & adult-mature (30-50) & 166.7 & 2 & 3 & 0.70900 & 0.000119696 \\
\hline 18 & female & senile $(60+)$ & 159.5 & 2 & 0 & 0.70866 & 0.000355163 \\
\hline 19 & prob. female & Infans2 (6-8) & 108.5 & 2 & 1 & 0.70699 & 0.001540981 \\
\hline 20 & male & adult-mature (30-50) & 173.9 & 2 & 2 & 0.70942 & 0.000176582 \\
\hline 21 & nd & Infans1 (1-3) & 75.3 & 2 & 1 & 0.70912 & 0.000033429 \\
\hline 22 & male & adult-mature (30-50) & 165.2 & 1 & 1 & 0.71247 & 0.002333257 \\
\hline 23 & prob. male & adult-mature $(30-50)$ & 162.0 & 1 & 1 & 0.70903 & 0.000096362 \\
\hline 24 & female & adult (20-24) & 158.0 & 2 & 2 & 0.70899 & 0.000125353 \\
\hline 25 & prob. male & adult (24-40) & 163.4 & 1 & 2 & 0.70872 & 0.000316272 \\
\hline 26 & prob. male & adult $(20+)$ & 164.3 & 2 & 3 & 0.70889 & 0.000198185 \\
\hline 27 & male & mature $(40-60)$ & 176.7 & 0 & 3 & 0.71300 & 0.002710145 \\
\hline 28 & prob. female & Infans2 (6-9) & 110.8 & 3 & 1 & 0.70911 & 0.000041207 \\
\hline 29 & female & senile $(60+)$ & & 1 & 0 & 0.70944 & 0.000193552 \\
\hline 30 & female & senile $(60+)$ & 163.5 & 1 & 0 & 0.70920 & 0.000023139 \\
\hline 31 & prob. male & Infans1 (0.5-2) & & 3 & 0 & & \\
\hline 32 & nd & $0-0.5$ & & 0 & 0 & & \\
\hline
\end{tabular}

In principle, the chronologically-structured sequence of enamel formation allows to determine in which age a hypoplastic line developed (Goodman, Rose 1990) (Figure 6). In the München-Perlach collective no hypoplasia were detected that had developed before the second year of life, which may suggest that there were few problems with children's diseases and malnutrition before this age. This finding is supported by the fact that none of the preserved deciduous teeth (representing the prenatal phase of development) displayed enamel hypoplasia. In most cases the hypoplasia formed between the age of two and five years with a maximum in the $4^{\text {th }}$ year of life.

A possible cause of the high stress level in this phase of childhood can be seen in the weaning phase and the loss of passive immunity involved; immunity that had been previously given to the child through maternal immunoglobulins (Stuart-Macadam 1985; Zink 1999). As a result the children get infected more easily with typical children's diseases like measles, mumps or chicken-pox, thus putting a great strain on the organism.

\section{Strontium isotope analysis}

Information as to methods, evaluation and the applied cut-off values can be taken from the contribution by Harbeck et al. (2016) and Haebler et al. (2006).

Strontium isotope analyses were carried out on 27 individuals from München-Perlach. The results show 
Figure 6. Frequency of enamel hypoplasias (related to the year of their development) in the München-Perlach collective.

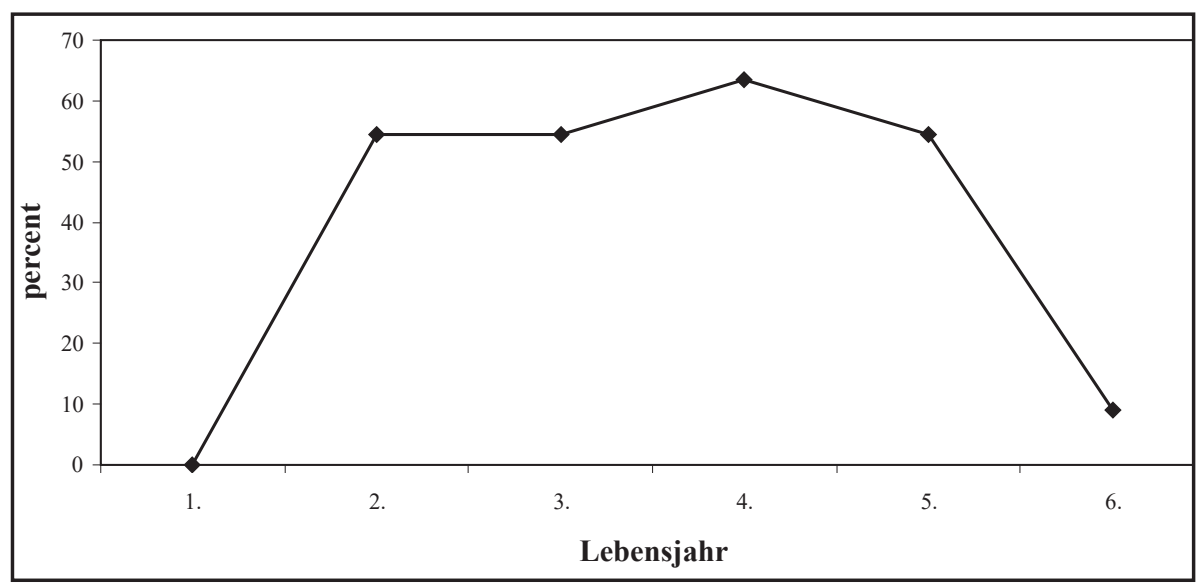

that four of them (14.8\%) did not consume food and drink from the local (geological) region in their childhood - which most likely indicates that they grew up somewhere else (burial no. 12, 19, 22, 27; cf. Table 6). With two (probable) female and two (probable) male individuals, their sex ratio is balanced. Besides three adult or mature individuals (burial no. $12,22,27$ ), a 6- to 8-year-old child (burial no. 19) also showed a non-local strontium signature (cf. Harbeck et al. 2016). The identified proportion of non-locals of $14.8 \%$ is very low compared to other contemporary collectives. The contribution by Harbeck et al. (2016) mentions proportions of $30 \%$ up to $70 \%$ of non-local individuals in a sample of four different necropoles. The low result of München-Perlach is remarkable, especially when compared with Unterhaching, a cemetery only $5 \mathrm{~km}$ further south, where $70 \%$ (the highest proportion determined) of the buried individuals had not spent their early years of life in the local region.

In two of the Perlach individuals (burial no. 22 and 27), the ${ }^{87} \mathrm{Sr} /{ }^{86} \mathrm{Sr}$ ratio is higher than the cut-off value of 0.7103 used here, indicating that they spent their childhood in a region dominated by bedrock containing granite or gneiss.

The strontium isotope signatures of the individuals from burial no. 12 and 19, on the other hand, show values below the cut-off value of 0.708 , thus suggesting bedrock dominated by volcanic rocks (for details, see Haebler et al. 2006; Harbeck et al. 2016). An interesting fact is that strontium ratios below 0.708 were found neither in the neighbouring Unterhaching necropolis nor in the Burgweinting collectives - all of the individuals identified as non-locals in these populations by their strontium signatures showed values higher than the upper threshold value of 0.7103 .

The four Perlach individuals identified as "non-locals" represent only a minimum number of people who had not spent their early years of life in the region. For instance, personal mobility within the large and geologically rather homogenous region between the Danube and the Alps cannot be detected by means of the strontium isotope method and the threshold values used here. Thus it is not possible to conclude that all the other individuals had spent their whole life in Perlach (further discussion in Harbeck et al. 2016).

The four people with strontium isotope signatures different from all the other individuals were not buried close to each other but rather at opposite ends of the cemetery: burial no. 22 is situated in the northwestern group of graves, burial no. 27 in the east of the cemetery, burial no. 12 lies in its southeastern part and burial no. 19 on the western border of the main group of graves ( $c f$. Figure 1). Two of them were buried with brooches, namely the woman in grave no. 12 and the person in grave no. 27 who was identified as male via morphological analysis of the skeleton but nonetheless was buried with an attire typical of females (for possible reasons for a discrepancy between anthropological sex and archaeological gender see Gärtner et al. 2013). The graves of the other two "non-locals" did not contain anything that would indicate wealth or high status, as can be assumed for the brooches and other jewellery. This refutes the (maybe rather naïve) idea that people with similar ${ }^{87} \mathrm{Sr} /{ }^{86} \mathrm{Sr}$ isotopic ratios would be buried close to each other because of their potentially similar life story. Furthermore, the hypothesis that people of higher status (indicated by rich grave goods) might be more likely to move to other regions within their lifetime - as the results for the richly-furnished Unterhaching graves seem to suggest - cannot be confirmed either.

\section{Conclusion}

Sex ratio and distribution of age-of-death of the individuals of the München-Perlach collective can be described as balanced and typical of the Early Middle Ages.

Yet, some anthropological data indicate none too favourable living conditions, especially when compared with those from the Burgweinting and Unterhaching necropoles, namely the high mortality rate of children, the fact that more individuals had died in the adult (instead of mature) age class and the frequency of stress markers. The total frequency of cribra orbitalia is comparable to that of the population of Wenigumstadt, while considerably fewer individuals from the Unterhaching and Burgweinting graveyards were affected. The anthropological analysis demonstrates that living conditions in München-Perlach measured on the basis of unspecific stress markers may have been less favourable than in the contemporary collectives of Burgweinting and Unterhaching. Still, it cannot be decided with certainty 
whether really "bad" or only rather ordinary average living conditions have to be assumed for Perlach, as it might well be possible that the individuals buried in the "reference necropoles" of Burgweinting and Unterhaching had lived under extraordinarily good living conditions. For further interpretation, additional representative cemetery collectives would be needed.

Furthermore, the Perlach population differs from the "reference necropoles" of Burgweinting and Unterhaching in regard to the number of individuals identified as "nonlocals" - a number which is considerably lower in Perlach. Again, a broader basis of comparison would be desirable.

\section{Acknowledgement}

This study was conducted with financial aid by the Gesellschaft für Archäologie in Bayern e.V. for laboratory costs. We would also like to thank Mike Schweissing for the mass spectrometry measurements of the Sr-isotopes and Anja Staskiewicz for her helpful comments and for translating large parts of the manuscript to English.

\section{References}

ACSÁDI, G., NEMERSKÉRI, J. 1970: History of human life span and mortality. Akademiai Kiado, Budapest.

AUFDERHEIDE, A., RODRIGUEZ-MARTIN, C. 1998: The Camebridge Encyclopedia of human paleopathology. University Press, Cambridge.

BENNIKE, P., LEWIS, M.E., SCHUTKOWSKI, H., VALENTIN, F. 2005 Comparison of child morbidity in two contrasting medieval cemeteries from Denmark. American Journal of Physical Anthropology 128, 734 746.

BOCQUET, J.P., MASSET, C. 1977: Estimateurs en Paléodémographie. L'Homme 17, 65-90.

CODREANU-WINDAUER, S., SCHLEUDER, R. 2013: Gräber des 5. Jahrhunderts von Regensburg-Burgweinting aus archäologischer und anthropologischer Sicht. Bericht der Bayerischen Bodendenkmalpflege 54, 2013, 351-362.

FEHR, H., LATER, C., VOLPERT, H.-P. 2005: Eine reiche Grabgruppe der frühen Merowingerzeit aus Unterhaching, Landkreis München, Oberbayern. Das archäologische Jahr in Bayern 2005, 93-96.

GÄRTNER, T., HAAS-GEBHARD, B., HARBECK, M., IMMLER, F., ROTT, A. 2013: Frühmittelalterliche Frauen in Waffen? Divergenzen zwischen der archäologischen und anthropologischen Geschlechtsansprache. Bayerische Vorgeschichtsblätter 79, 2014, 219 240.

GOODMAN, A.H., ROSE, J.C. 1990: Assessment of systematic physiological perturbations from dental enamel hypoplasias and associated histological structures. Yearbook of Physical Anthropology 33, 59-110.

GRUPE, G. 1995: Zur Ätiologie der Cribra orbitalia: Auswirkung auf das Aminosäureprofil im Knochenkollagen und den Eisengehlat des Knochenminerals. Zeitschrift für Morphologie und Anthropologie 81, 125-137.

GRUPE, G., CHRISTIANSEN, K., SCHRÖDER, I., WITTWERBACKOFEN, U. 2005: Anthropologie. Ein einführendes Lehrbuch. Springer, Berlin, Heidelberg, New York.

HAAS-GEBHARD, B., FEHR, H. 2013: Unterhaching. Eine Grabgruppe der Zeitum 500 n. Chr. bei München. Abhandlungen und Bestandskataloge der Archäologischen Staatssammlung 1. Archäologische Staatssammlung, München.

HAEBLER, K., ZINTL, S., GRUPE, G. 2006: Lebensbedingungen und
Mobilität im frühmittelalterlichen Perlach. Bulletin der Schweizerischen Gesellschaft für Anthropologie 12, 2, 47-62.

HARBECK, M., MÜLLER, R., CODREANU-WINDAUER, S., HABERSTROH, J. 2016: Living at the outskirts of the former Roman Empire. A study of 5 th century Bavarian burials. IANSA VI/1/2016.

HARBECK, M., SEILER, M., HEGERL, C., BAUER, S., GRUPE, G. 2013: Eine eingewanderte Familie von hohem Rang? Anthropologische Charakterisierung der frühmittelalterlichen Grablege von Unterhaching im zeitgenössischen Kontext. In: B. Haas-Gebhard, H. Fehr (Eds.): Unterhaching. Eine Grabgruppe der Zeit um 500 n. Chr. bei München. Abhandlungen und Bestandskatalog der Archäologischen Staatssammlung München 1, 209-222.

HERRMANN, B., GRUPE, G., HUMMEL, S., PIEPENBRINK, H., SCHUTKOWSKI, H. 1990: Prähistorische Anthropologie. Leitfaden der Feld- und Labormethoden. Springer, Berlin, Heidelberg.

HILLSON, S.W., BOND, S. 1997: Relationship of enamel hypoplasia to the pattern of tooth crown growth: A discussion. American Journal of Physical Anthropology 104, 89-103.

KNAUT M.1993: Die alamannischen Gräberfelder von Neresheim und Kösingen, Ostalbkreis. Forschungen und Berichte zur Vor- und Frühgeschichte in Baden-Württemberg 48. Theiss, Stuttgart.

KOKKOTIDIS, K.G. 1999: Von der Wiege bis zur Bahre - Untersuchungen zur Paläodemographie der Alamannen des frühen Mittelalters. MS. Dissertation. Deposited: University Library in Cologne (Köln), Germany.

LANGENSCHEIDT, F. 1985: Methodenkritische Untersuchungen zu Paläodemographie am Beispiel zweier fränkischer Gräberfelder. Bundesinstitut für Bevölkerungsforschung, Wiesbaden.

LEWIS, M., ROBERTS, C. 1997: Growing pains: the interpretation of stress indicators. International Journal of Osteoarchaeology 7, 581-586.

LOHRKE, B. 2004: Kinder in der Merowingerzeit. Gräber von Mädchen und Jungen in der Alamannia. Freiburger Beiträge zur Archäologie und Geschichte des ersten Jahrtausends 9. Leidorf, Rahden/Westfalen.

MARTIN, M. 1984: Weinsiebchen und Toilettgerät. In: Der spätrömische Silberschatz von Kaiseraugst. Basler Beiträge zur Ur- und Frühgeschichte 9, Habegger, Derendingen, 97-132.

MASSLER, M., SCHOUR, J., LINDEN, C.T. 1965: Medica-Bildatlas des Mundes und der Zähne. Anatomie und Pathologie. Medica Verlag, Stuttgart, Wien, Zürich.

OWENS, I. P. F. 2008: Sex differences in mortality rate. Science 297, 20082009.

RIBOT, I., ROBERTS, C. 1996: A Study of Non-specific Stress Indicators and Skeletal Growth in Two Mediaeval Subadult Populations. Journal of Archaeological Science 23, 67-79.

SCHULTZ, M. 1988: Paläopathologische Diagnostik. In: Knußmann, R. (Ed.): Anthropologie der vergleichenden Biologie des Menschen. Gustav Fischer Verlag, Stuttgart, 480-496.

SCHUTKOWSKI, H., GRUPE G. 1997: Zusammenhänge zwischen Cribra orbitalia, archäometrischen Befunden am Skelett und Habitatbedingungen. Anthropologischer Anzeiger 55, 155-166.

STEINBOCK, R.T. 1976: Paleopathological diagnosis and interpretation: bone diseases in ancient human populations. Thomas, Springfield.

STECKEL, R. H., LARSEN, C. S., SCIULLI, P. W., WALKER, P. 2005: The Global History of Health Project. Data Collection Codebook. http:// global.sbs.ohio-state.edu

STUART-MACADAM, P. 1985: Porotic hyperostosis: Representative of a childhood condition. American Journal of Physical Anthropology 66, 391-398.

SULLIVAN, A. 2005: Prevalence and etiology of acquired anemia in Medieval York, England. American Journal of Physical Anthropology 128, 252-272.

STROTT, N. 2006: Paläodemographie frühmittelalterlicher Bevölkerungen Altbaierns - Diachrone und allopatrische Trends. MS. Dissertation. Deposited: Institut für Anthropologie und Humangenetik, LudwigMaximilians-Universität München.

TIMMERMANN, M. 2009: Das Ihlower Zisterzienserkloster: Beten, Arbeiten und heilsames Leben im Mittelalter! Eine anthropologische Untersuchung. MS. Dissertation. Deposited: Freien Universität Berlin.

VOLPERT, H.-P. 2004/2005: Die römische Siedlung von München-Perlach, Schmidbauerstraße (Grabung 1999/2000). Bericht der Bayerischen Bodendenkmalpflege 45/46, 2004/05, 271-279.

WAHL, J. 1992: Der anthropologische Befund - der Heidelberger 
Spitalfriedhof. In: Flüeler M., Flüeler N. (Eds.): Stadtluft, Hirsebrei und Bettelmönch. Landesdenkmalamt Baden-Württemberg, Theiss, Stuttgart, 479-485.

WALKER, P. L., BATHURST, R. R., RICHMAN, R., GJERDRUM, T. ANDRUSHKO, V. A. 2009: The causes of porotic hyperostosis and cribra orbitalia: A reappraisal of the iron-deficiency-anemia hypothesis. American Journal of Physical Anthropology 139, 109-125.

WAMSER, L. (Ed.) 2010: Karfunkelstein und Seide. Neue Schätze aus Bayerns Frühzeit. Ausstellungskatalog Archäologische Staatssammlung München. Pustet, Regensburg.

WAPLER, U., CRUBÉZY, E., SCHULTZ, M. 2004: Is cribra orbitalia synonymous with anemia? Analysis and interpretation of cranial pathology in Sudan. American Journal of Physical Anthropology 123, 333-339.

WINGHART, S. 1995: Bemerkungen zu Genese und Struktur frühmittelalterlicher Siedlung im Münchner Raum. In: Kolmer L., Segl P. (Eds): Regensburg Bayern und Europa. Festschrift für Kurt Reindel zu seinem 70. Geburtstag. Universitäts-Verlag, Regensburg, 7-47.

ZINK, A. 1999: Kindersterblichkeit im frühen Mittelalter: morphologische und paläopathologische Ergebnisse an der Skeletserie von Altenerding, Ldkr. Erding, Bayern. Cuvillier, Göttingen.

ZINTL, S. 2004/2005: Das frühmerowingische Gräberfeld von MünchenPerlach. Bericht der Bayerischen Bodendenkmalpflege 45/46, 281-370. 
